\title{
Process Evaluation: Standard, Effectiveness, Efficiency and Sustainability of Maternity Nursing Care
}

\author{
Laili Rahayuwati, Ermiati, Mira Trisyani \\ Fakultas Keperawatan, Universitas Padjadjaran \\ Email:laili.rahayuwati@unpad.ac.id
}

\begin{abstract}
Although globally there is a change in the trend of epidemiology from infectious diseases to chronic diseases, the prevalence and incidence of infectious diseases as well as MMR (Maternal Mortality Rate) and IMR (infant mortality rate) in Indonesia is still high. In year 2000, Faculty of Nursing of the Universitas Padjadjaran in collaboration with Hasan Sadikin Hospital built a model of treatment room, which was affiliated with obstetric gynecology room for improving integrated quality of health care services and education. The model built in this room aimed to : 1) Improve the quality of health care service; 2) to develop the student's experiences with patients; 3) Provide quality nurse education to support students; 4) encourage students to improve the results of clinical pretice. The objective of process evaluation in this study was to give an insight to an appropriate model for maternity nursing service. This results showed on the one hand, there are some records not yet achieved an ideal standard, lack of effectiveness and efficiency of care delivery, namely: 1 ) the ratio of midwives and patients are not ideal ; 2 ) No one consultant obstetrician gynecologist and one doctor for every room . As well as challenges to sustainability care that meets the standards of maternity care. Conclusion: this study recommends to take a comprehensive strategic planning for improving nursing and midwifery services that involve all relevant stakeholders in the government, civil society, service delivery, education, and professional organizations.
\end{abstract}

Keywords: Effectiveness, efficiency, evaluation, maternity nursing care, standard.

\section{Proses Evaluasi: Standar, Efektifitas, Efisiensi, dan Keberlangsungan Pelayanan Keperawatan Maternitas}

\begin{abstract}
Abstrak
Meskipun secara global ada perubahan dalam tren epidemiologi dari penyakit menular ke penyakit kronis, prevalensi dan insiden penyakit menular serta MMR (Angka Kematian Ibu) dan AKB (angka kematian bayi) di Indonesia masih tinggi. Tahun 2000, Fakultas Keperawatan Unpad bekerja sama dengan Rumah Sakit Hasan Sadikin, Bandung membangun sebuah model dari ruang perawatan, yang berafiliasi dengan ruang obstetrik ginekologi. Model yang dibangun tersebut bertujuan untuk; 1) meningkatkan kualitas pelayanan kesehatan;2) pengembangan pengalaman mahasiswa dengan pasien; 3) penyediaan pendidik perawat yang berkualitas untuk mendukung mahasiswa; 4) mendorong mahasiswa untuk meningkatkan hasil praktek klinis. Tujuan dari penelitian ini adalah memberikan informasi dan evaluasi tentang standar, efektifitas, efisiensi, dan keberlangsungan (sustainaibility) pelayanan keperawatan maternitas. Hasil penelitian menunjukkan: di satu sisi, ada beberapa catatan tidak belum tercapainya standar ideal, kurang efektivitas dan efisiensi perawatan persalinan, yaitu: 1) rasio bidan dan pasien tidak ideal;2) ada satu konsultan ginekolog obstetri dan satu dokter untuk setiap kamar. Serta tantangan terhadap keberlangsungan asuhan perawatan maternitas yang memenuhi standar. Kesimpulan: Penelitian ini merekomendasikan untuk mengambil perencanaan strategis yang komprehensif untuk meningkatkan pelayanan keperawatan dan kebidanan yang melibatkan semua pihak terkait di pemerintah, masyarakat sipil, pelayanan, pendidikan, dan organisasi profesi
\end{abstract}

Kata kunci: Asuhan keperawatan maternitas, efektifitas, efisiensi, evaluasi, standar. 
Laili Rahayuwati : Standard, Effectiveness, Efficiency and Sustainability of Maternity Nursing Care

\section{Introduction}

WHO, 2008 showed that maternal mortality still leaves a health issue in the country. This condition happened even though there have been many positive developments in medical technology and maternity nursing care. Based on Development Millenium Goal 2014 and Survei Demografi Kesehatan Indonesia (SKDI, 2012), in year 2007 there were 228 deaths per 100,000 live births. Additionally, in year 2012 there were increasing 359 deaths per 100.000 live births. Nevertheless, the target of Global MDG's $5^{\text {th }}$ should be reached the target to be 70 deaths per 100.000 live births (Charmin, 2015; BPS, 2015).

Indonesia Ministry of Health released information during period 2010-2013 of maternal deaths were caused by haemorrhage, hipertention, infection, abortus. Furthermore, some of the major causes of maternal mortality in Indonesia could be grouped into preventable deaths, namely: bleeding (30\%), eclampsia $(25 \%)$, infection $(12 \%)$, puerperal complications (8\%), abortion complications $(5 \%)$, and delayed parturition (5\%). In addition, about $20 \%$ of maternal mortality problems were caused by cases indirectly related to pregnancy and childbirth, which included: anemia, malaria, hepatitis, and HIV / AIDS. And the highest number of deaths actually occurred during childbirth or because of direct factors, such as obstetric complications, bleeding and eclampsia (Dinkes, 2013).

Hospital is part of the system of health care practices that provide services to the society in order to improve health status. Hasan Sadikin Hospital is categorized as a referral hospital which have functions to: 1) represent a health care institution responsible for handling emergency medical care; 2) be a teaching hospital for health care providers (medical staff); 3 ) provide health care services that play a significant role in improving the standard of public health in West Java.

Based on the chronicle of the year 2000 at the Hasan Sadikin Hospital, the nursing team sponsored by the Faculty of Nursing, Padjadjaran University, has built a model of treatment room. This model room was built to 1) improve the quality of health care services; 2) develop student-patient relation experience; 3) provide quality nursing educators to support students' activities; 4) encourage students to improve the results of clinical practice.

Nurses in the hospital have an important role as one of the health care team. As a caregiver, nurses provide patient care, in collaboration with doctors and other health care professionals in providing health care services to the patients. Nurses also coordinate with patients and families to improve the quality of service and the quality of life of patients. As an educator, nurses provide education to patients, also serve prevention of infection, patient comfort and safety measure. As an advocate, nurses facilitate and empower the patient and family in order to improve the health status of patients in various situations (Stanhope \& Lancaster, 1998).

The concept of process evaluation in this study aims to produce documentation in a program and to determine whether it has fulfilled the existence and availability of physical elements and the structure of the program. Process evaluation is part of the formative evaluation aimed at assessing whether certain elements, such as facilities, staff, space, or services provided or established, are in accordance with the given program planning. Process evaluation also assesses the planning/development of the program to support the development of the program according to patient's needs. In this case, the process evaluation also involves documentation and specific description of the maternity nursing care program, which includes: forms, actors and activity time (WHO, 2010).

In this regard the process evaluation includes: the monitoring of the participation of human resources until the level of program implementation. This process evaluation is supported by the following documentations: the existence of health and non-health staff, the patient's condition, the quality of implementation plan, the suitability of plan to its implementation, methods, materials, media, and instruments being used.

The general objective of the study is to assess the maternity nursing care in the obstetric gynecology room. The specific 
Laili Rahayuwati : Standard, Effectiveness, Efficiency and Sustainability of Maternity Nursing Care

objectives are: 1) to describe the relevance of maternity nursing care in the hospital with the "gold standard" maternity nursing care; 2) to assess the effectiveness and quality of maternity nursing care; 3) to identify the efficiency of maternity nursing care; 4) to describe the "sustainability" maternity nursing care; 5) to recommend the maternity nursing care model in order to improve the quality of care/service.

\section{Method}

The study was conducted at the Hasan Sadikin Hospital, Bandung, especially in Kemuning ward for patients with obstetric gynecological cases, including postpartum and reproductive nursing health. The case study was conducted as a most effective evaluation strategy to obtain information about the activities of the program, both in specific and general. This case study was used to analyze related situation, such as: the location of health care services, the level of skill and coordination between nurses and nursing students, and the documentation of maternity nursing activities.

The variable in this study was a maternity nursing care program related to obstetric gynecologic case, as well as the standard of child birth maternity nursing care. The relevant indicators in measuring the variables were: substantial values of characteristic on each activity of nursing care, the comparison of maternity nursing care with the previous reports before the implementation of room model.

Furthermore, the measurement of effectiveness of maternity nursing care quality referred to: whether the program met its intended purpose; the quality of nurses improved professionally; and improvement of accountability of nursing students' standard of assessment. Meanwhile the efficiency of the maternity nursing services referred to: whether the results of the program could be achieved at a low cost and how the continuity of maternity nursing care in relation with a number of indicators, such as the well-being of nurses and service partnership model.

The population was health care workers, students and patients who interacted in the Kemuning ward over a period of one month. Samples were taken by accidental sampling, both nurses (5) and nursing students (15) who were undergoing learning process in Kemuning ward for one month. Besides, the questioners were also distributed to 22 patients as repondents. This predicted number was counted based on the average number of confined patients in the ward over the period of three weeks.

Primary data were collected through: 1) interviews with health care workers and nursing students; 2) answering the questionnaires, with the guide of data collectors, by 22 respondents; 3 ) observation of clinical situation in the Kemuning ward in relation to maternity nursing care processes. Meanwhile, secondary data were obtained from documentation of the situation in Kemuning ward. This documentation method was conducted through monitoring the meetings of health care personnel and the evaluation process of students' guidance on clinical competence and other relevant matters.

The research instruments were interview guides and questionnaires. Interviews were conducted using interview guide, which included the general questions on the situation of the treatment ward, and specific questions being conducted specifically in accordance with the explanation of informant about aspects of maternity nursing care being understood.

Qualitative data analysis was done by using several dimensions which would be analyzed based on content analysis and group categories

\section{Result}

\section{Evaluation of Maternity Nursing Care}

Evaluation of nursing care is the assessment of nursing practice model, which aims to assess the effectiveness of a given health care service. Evaluation in its simplest form is the process that determines whether or not a service is appropriate. This process involves measurements, observations, and 
Laili Rahayuwati : Standard, Effectiveness, Efficiency and Sustainability of Maternity Nursing Care

comparisons based on several criteria or standards.

There are three types of evaluation, namely: process, impact, and outcome. This study of process evaluation is used to assess the elements of program development, particularly in assessing the quality of the program, the coherence between the plan and program, as well as the achievement of the program. Process evaluation can be done to provide assessment throughout the whole process of the program, beginning from planning to the final stage of activities and the follow-up plan. During planning stage, the evaluation process will focus on the quality, suitability of materials developed as well as the approach taken. As for the execution stage, the evaluation process aims to assess the scope of the program, level of execution of all programs, identification of potential problems that arise in the implementation and the force of implementation. Process evaluation is important in understanding, interpreting and explaining a lot of data that will be collected in the evaluation to assess its impact (Round, Marshal \& Horton, 2005).

Process evaluation is an important link in understanding the implementation of program and to improve the effectiveness of intervention. Moreover, nowadays many health care programs perform and develop interventions; thus, there is a great need to understand the theoretical construction in the planning and implementation of the program (Green, Kreuter, 2000). Understanding the mechanism of how a construction can produce a change (success or failure) is the key to improve and enhance the effectiveness of the intervention.

\section{Standard of Maternity Nursing Care}

In general, health care professionals who are competent in collaborative maternity care are: obstetricians, midwives, physicians, anesthetists, pediatricians, maternity nurses, neonatal nurses, pathologists, ultrasound, social workers, psychologists, and physiotherapists. In the professional nursing formal education, the competence for maternity nursing care is also prepared for this area. In addition in some situations of nursing practices in Indonesia, it is commonly found that maternity nursing care is offered by professional collaboration of nurses, obstetricians, and midwives. Furthermore, most important role of the nurse is to offer nursing care during the antenatal, delivery and post-natal care.

\section{Relevance of Maternity Nursing Care with Gold Standard}

Maternity nursing care provides an important foundation for promoting the health and welfare of mothers and newborns. The term "maternity nurse" has different meanings in different countries. In England and the United States there is a single authority, like the Council of Nursing and Midwifery (Nurse Midwifery Council). Meanwhile, in some countries there is no standardize yet on maternity nursing license, including Indonesia. Some countries require nurses who have passed the exam and completed their nursing education to be trained as maternity nurses. Even some countries have developed integrated maternity services performed by well trained maternity nurses in hospitals and maternity clinics. This situation is largely determined by the decision makers in each country to apply the global standards. Some countries adopt certain stages in accordance with the needs of the country.

\section{Effectivenes and Quality of Maternity Care in Hasan Sadikin Hospital}

Overall, maternity nursing focuses on the well-being of mother and child. It focuses on the emotional and physical well-being of both: mother and child. Maternity nurses have role to give emotional support as well as provide physical care for both mother and infant. The objectives of maternity nursing care are: 1) To help mothers feel comfortable handling their babies; 2) To show first time mothers how to wash the baby; 3) To show mothers how easy it is to feed, change and dress the newborn; 4) To organize the clothing, toys and other accoutrements of the baby; 5) To prepare necessary meals; 6) To pass on knowledge of the strengths and weaknesses and pros and cons of baby care issues, e.g. cloth diapers 
Laili Rahayuwati : Standard, Effectiveness, Efficiency and Sustainability of Maternity Nursing Care

Table 1 The Relevance of Maternity Nursing Curriculum and Services Standards

\begin{tabular}{|c|c|c|c|}
\hline & \multicolumn{3}{|c|}{ Maternity Nursing Standards } \\
\hline & Global & National & $\begin{array}{l}\text { Local Hospital } \\
\text { (implementation) }\end{array}$ \\
\hline Professional involved & Nurse, Midwife, Nurse-midwifery & Midwife, Nurse & Midwife \\
\hline Professional roles & $\begin{array}{l}\text { (WHO, 2008, 2009, 2010) } \\
\text { Nurse } \\
\text { - Nursing encompasses autonomous } \\
\text { and collaborative care of } \\
\text { individuals of all ages, families, } \\
\text { groups and communities, sick or } \\
\text { healthy and in all settings. } \\
\text { Midwife } \\
\text { The midwife works in partnership } \\
\text { with women to give the necessary } \\
\text { support, care and advice during } \\
\text { pregnancy, labour and the } \\
\text { postpartum period, to conduct } \\
\text { births on the midwife's own } \\
\text { responsibility and to provide care } \\
\text { for the newborn and the infant. }\end{array}$ & $\begin{array}{l}\text { Nursing Association } \\
\text { Nurse } \\
\text { Nursing encompasses } \\
\text { collaborative care of } \\
\text { individuals of all ages, } \\
\text { families, groups and } \\
\text { communities in all } \\
\text { settings. } \\
\text { Midwife Association } \\
\text { Midwife: } \\
\text { Holistic care for normal } \\
\text { and physiology life } \\
\text { cycle of women }\end{array}$ & $\begin{array}{l}\text { Midwife } \\
\text { - Responsibile } \\
\text { for and to } \\
\mathrm{p} \mathrm{r} \text { o } \mathrm{i} \mathrm{d} \text {. } \\
\text { care for the } \\
\text { newborn and } \\
\text { the infant also } \\
\text { medical care } \\
\text { in reproductive } \\
\text { cases. }\end{array}$ \\
\hline Education level & $\begin{array}{l}\text { Nurse: Diploma, Doctoral Level } \\
\text { Nurse-Midwife: Masteral Level } \\
\text { Midwife: Diploma Level }\end{array}$ & $\begin{array}{l}\text { Nurse: Secondary Level - } \\
\text { Doctoral Level } \\
\text { Midwife: Diploma - Masteral } \\
\text { Level }\end{array}$ & $\begin{array}{l}\text { Midwife: Diploma } \\
\text { Level }\end{array}$ \\
\hline $\begin{array}{l}\text { Competency in the } \\
\text { curriculum }\end{array}$ & $\begin{array}{l}\text { Nurse: } \\
\text { Nursing care during antenatal } \\
\text { (normal and high risk); intranatal; } \\
\text { post natal (normal, complication); } \\
\text { baby born; climacterium } \\
\text { (pre- postmenopause); health } \\
\text { reproduction problem; ethical and } \\
\text { managerial approach; research } \\
\text { Midwife } \\
\text { In partnership with the woman, } \\
\text { upholds each woman's right to } \\
\text { free and informed choice, collates } \\
\text { and documents comprehensive } \\
\text { assessments of the woman and/ } \\
\text { or baby's health and wellbeing, } \\
\text { maintains purposeful, on-going, } \\
\text { updated records and makes them } \\
\text { available to the woman and other } \\
\text { relevant persons, evaluate their } \\
\text { practices, share knowledge and } \\
\text { promotes research }\end{array}$ & $\begin{array}{l}\text { AIPNI (The Association } \\
\text { of Indonesian Nursing } \\
\text { Education Institution), 2010 } \\
\text { Nurse: } \\
\text { - Nursing care during } \\
\text { antenatal (normal and } \\
\text { high risk); intranatal } \\
\text { (normal and invasive); } \\
\text { post natal (normal, } \\
\text { complication); baby } \\
\text { born; family planning; } \\
\text { climacterium (pre- } \\
\text { pos t m e p a u e ); } \\
\text { reproduction problem } \\
\text { (cancer, myoma, HIV/ } \\
\text { AIDS, dismenorhea, } \\
\text { STI, PMS); health } \\
\text { promotion; ethical and } \\
\text { managerial approach; } \\
\text { research } \\
\text { Midwife the } \\
\text { Implementing } \\
\text { midwifery, thecial, } \\
\text { behavior, public health } \\
\text { science, identification } \\
\text { research for midwery } \\
\text { implementation }\end{array}$ & $\begin{array}{l}\text { Nursing student } \\
\text { assists the medical } \\
\text { care of midwife }\end{array}$ \\
\hline
\end{tabular}


Laili Rahayuwati : Standard, Effectiveness, Efficiency and Sustainability of Maternity Nursing Care

\begin{tabular}{|c|c|c|c|}
\hline & \multicolumn{3}{|c|}{ Maternity Nursing Standards } \\
\hline & Global & National & $\begin{array}{l}\text { Local Hospital } \\
\text { (implementation) }\end{array}$ \\
\hline Services & $\begin{array}{l}\text { Nurse } \\
\text { Nurse provides two related and } \\
\text { integrated services, namely: 1) pre- } \\
\text { birth care, to help the mother and } \\
\text { the family during their pregnancy } \\
\text { and afterwards, prepares the family } \\
\text { for the entire birthing experience; } \\
\text { 2) post-natal care, to advise mothers } \\
\text { on things such as post natal care of } \\
\text { themselves and their newborns. } \\
\text { It includes the promotion of health, } \\
\text { prevention of illness, and the care } \\
\text { of ill, disabled and dying people, } \\
\text { and advocacy. } \\
\text { Midwife } \\
\text { Maternity care includes preventive } \\
\text { measures, the promotion of normal } \\
\text { birth, the detection of complications } \\
\text { in mother and child, the accessing } \\
\text { of medical care or other appropriate } \\
\text { assistance and the carrying out of }\end{array}$ & $\begin{array}{l}\text { Nurse } \\
\text { - Women health nursing } \\
\text { care of intranatal, partus } \\
\text { and post partum till } 28 \\
\text { days in normal or high } \\
\text { risk condition; health } \\
\text { reproduction; nursing } \\
\text { research } \\
\text { Midwife } \\
\text { Holistic care for normal } \\
\text { and physiology life } \\
\text { cycle of women }\end{array}$ & $\begin{array}{l}\text { Midwife } \\
\text { M a t e r n it y } \\
\text { care includes } \\
\text { p reventive } \\
\text { measures, the } \\
\text { promotion of } \\
\text { normal birth, } \\
\text { the detection of } \\
\text { complications } \\
\text { in mothers } \\
\text { Nurse in } \\
\text { Nurses in } \\
\text { m a t e r n it y } \\
\text { settings have } \\
\text { a role to } \\
\text { compliment } \\
\text { and support, } \\
\text { but do not } \\
\text { substitute the } \\
\text { midwives }\end{array}$ \\
\hline
\end{tabular}

versus pampers, bottle feeding versus breast feeding; 6) To wash and sterilize bottles.

There are several types of nursing program: 1) Increasing access to health care and improve overall health and well-being; 2) Providing accessible, respectful, and non-judgmental primary care; 3) Referring patients to health and social services that address the social determinants of health; 4) Collaboratively developing patient health care plans; 5) Providing health education; 5) Advocacy (decreasing barriers in health care and assist patients in navigating the health and social service system and advocate for pateints' needs within this system).

\section{Obstetric Gynecology Room in Hasan Sadikin Hospital, Bandung}

The vision of Hasan Sadikin Hospital is: To be a world class hospital in providing services, education and research in year 2017. Its mission is: to be committed to a quality of health services and an integrated education and research. Meanwhile, the motto is "Your Health is Our Priority". Nevertheless, the Kemuning room's vision is to be national regional hospital in providing services, education and research year of 2013 (Hasan Sadikin, 2002).

As a referral hospital, Hasan Sadikin Hospita's maternity care standards are related to: hyperemesis gravidarum, abortion, intranatal, ectopic pregnancy, cervical cancer, post partum, eclampsia, and all reproduction health cases as total maternity care. These standard procedures have several steps, such as: assessment, data analysis, diagnosis and intervention planning. In addition, the standards of operating procedures for nurses are: high risk perinatal, postpartum exercise (2-40 days) after child birth, baby bathing, and baby weighing.

Health professional staffs in Hasan Sadikin Hospital, especially in obstetric gynecology room were 15 personnels, consist of: midwife four-year diploma (4 personnel) and midwife three-year diploma ( 9 person), 2 nurses (1 maternity specialist, 1 three year diploma). In addition, nursing students (three years diploma program and nursing bachelor program, and nurse profession) have been practicing in this hospital, aside from the obstetric and gynecology students 
Laili Rahayuwati : Standard, Effectiveness, Efficiency and Sustainability of Maternity Nursing Care

and midwife three-year diploma students. The ratio between midwife and patient on daily average is $1: 14$. There are good room facilities, including social health insurance provided by government.

The roles of midwives are: 1) to provide maternity nursing care of the patient related to human needs; 2) to provide information on reproduction health and disease prevention to patient; 3 ) to provide the rehabilitation of patient; 4) to support ill patient in the terminal condition. The role of the obstetrician consultant in Kemuning room on the labor ward is to ensure a high standard of care for women and their babies with complex medical or obstetric needs, and to be available for acute, severe and oftenunpredictable life threatening emergencies. The presence of obstetrician consultants is required in the following clinical situations: eclampsia, maternal collapse (such as massive abruption, septic shock), caesarean section for major placenta praevia, postpartum haemorrage of more than 1.5 liters, where the haemorrhage is continuous and massive obstetric haemorrhage protocol has been instigated, and laparotomy when requested.

As education hospital, the role of the provider is to increase the students' competence, which includes cognitive, affective, and psychomotor competence related to patient's health and well-being. In addition, as research hospital, the goal of the institution is to increase the nursing care and general health care of patients.

The services model in the obstetric and gynecology (Obgyn) ward is a teamwork model. Obgyn ward is divided into three rooms: first room provides services for obstetrical cases; second room for tropoblast cases; and third room for gynecological cases. The challenge in providing these services is the ratio of health provider with patients. There were some concerns with regard to the effectiveness of maternity care, namely: 1) the ratio of midwife and patient was not ideal. The maternity care was a bit effective only in the morning, where the students (midwife, nurse) assist in providing some phases of health services: from assessment, implementation to evaluation of patient; 2) there was one Obgyn consultant and one medical doctor for every room. MD conducted physical examination of patients every morning. Most of therapy delegation to midwife has been done by direct communication, rather than through medical records. The effectiveness indicator of maternity care will be shown in Table 2 .

\section{Efficiency of Maternity Nursing Services}

The efficiency of maternity nursing care services can be measured by the Length of Stay (LOS) of patients and the Bed Occupational Rate (BOR). LOS and BOR in January-April 2012 showed: 93,9\% - 5 days; $84,40 \%$ - 5 days; $93,02-5$ days; $87,6 \%$ (4 days. The ideal time span of LOS in obgyn room is 2.28 days (Ministry of Health and Population, 1997). The study showed that the average LOS in the obgyn romm was still 4.75 days. It showed that the services need more improvement to reduce LOS. Based on the interview, one of the reasons of high average of LOS was documentation problem and flow of consultation between midwife and obgyn specialist.

\section{Sustainability of Maternity Services}

The sustainability of maternity services in hospital was related to the partnership and development of services. Generally, there are several types of relationship between midwives and other health professionals: 1) the relation with medical doctor showed the communication as a social function, which was more of a delegating, rather than collaboration; 2) the relation with nutritionist was limited to communicating about the name and diagnosis of the patient; 3 ) the relation with medical technologist and radiographer was rarely happened, because the family or students accompanied the patient; 4) the relation with pharmacist usually happened in the morning during the time of administering medicine, while patient's family had the responsibility to take medicine in the afternoon until night.

Nevertheless, the collaboration between nurse and midwife is very important to note. A midwife in obgyn room said that they changed the term "maternity nursing care" to "midwife care" in order to provide maternity 
Laili Rahayuwati : Standard, Effectiveness, Efficiency and Sustainability of Maternity Nursing Care

Table 2 The Effectiveness Analysis of Maternity Care in Obgyn Room

\begin{tabular}{|c|c|c|c|}
\hline Item & Ideal & Actual (Observation) & Problem \\
\hline \multicolumn{4}{|l|}{ Services } \\
\hline $\begin{array}{l}\text { Flow of Care of } \\
\text { new patient }\end{array}$ & $\begin{array}{l}\text { - Accepting patient and } \\
\text { patient family, and } \\
\text { introducing the name } \\
\text { of provider } \\
\text { Checking the } \\
\text { emergency status } \\
\text { - Preparing the room } \\
\text { appropriately } \\
\text { - Assessment } \\
\text { - Collaboration with } \\
\text { medical doctor } \\
\end{array}$ & $\begin{array}{l}\text { It was done; except that it } \\
\text { was only good enough on } \\
\text { room preparation }\end{array}$ & $\begin{array}{l}\text { The risk of unoptimizing } \\
\text { acceptance of new patient. }\end{array}$ \\
\hline $\begin{array}{l}\text { Implementation of } \\
\text { human basic needs }\end{array}$ & $\begin{array}{l}\text { Turning of shift } \\
\text { should be done } \\
\text { with checking the } \\
\text { patient, including } \\
\text { bed number number, } \\
\text { patient's name, age, } \\
\text { medical diagnosis, } \\
\text { i m p l e n t a t i o n, } \\
\text { therapies. } \\
\text { Team work would } \\
\text { be effective with } 27 \\
\text { midwifes }\end{array}$ & $\begin{array}{l}\text { Turning of shift had been } \\
\text { done only in front of the } \\
\text { room } \\
\text { Teamwork method was } \\
\text { not effective because of } \\
\text { the limited number of } \\
\text { total midwifes (only 21) }\end{array}$ & $\begin{array}{l}\text { The risk of unoptimizing } \\
\text { maternity care }\end{array}$ \\
\hline Documentation & $\begin{array}{l}\text { - Filling up the form } \\
\text { to record patient's } \\
\text { condition } \\
\text { - Midwife's diagnosis } \\
\text { - Evaluation of patient } \\
\text { condition }\end{array}$ & $\begin{array}{l}\text { Complete Assessment: } \\
\text { - Medical record: only } \\
32.35 \% \\
\text { - } \quad \text { Patient demographic: } \\
\text { only } 12 \% \\
\text { - } \quad \text { Sign and symptom: } 91 \% \\
\text { - } \quad \text { History of disease: } \\
45.5 \% \text { } \\
\text { Physical examination: } \\
45 \%\end{array}$ & $\begin{array}{l}\text { Unoptimized maternity care } \\
\text { documentation }\end{array}$ \\
\hline & & $\begin{array}{ll}\text { Midwife diagnosis: } \\
\text { - } \quad \text { Diagnosis: } 72.8 \% \\
\text { - } \quad \text { Implementation } 97.1 \%\end{array}$ & \\
\hline Discharge Planning & $\begin{array}{l}\text { - Complete the patient's } \\
\text { biodata } \\
\text { Assessment of } \\
\text { patient and family's } \\
\text { knowledge on disease, } \\
\text { medicine, wound care } \\
\text { Conducting health } \\
\text { education }\end{array}$ & $\begin{array}{l}\text { Had been done without } \\
\text { documentation }\end{array}$ & $\begin{array}{l}\text { Unoptimized information } \\
\text { needs of patient }\end{array}$ \\
\hline
\end{tabular}

Source: Primary Data

care in Obgyn room. However, some nursing terms could not be implemented by midwife because of different competence, especially in the gynecological services. Therefore, in those cases, they needed nurses to give better services to patients.

\section{Discussion}

In several countries, maternity nursing care can be provided by health professionals such as nurses or midwives. Nowadays, nurses and midwives in the world come from a variety of 
Laili Rahayuwati : Standard, Effectiveness, Efficiency and Sustainability of Maternity Nursing Care

backgrounds including: 1) certified nursing; 2) midwifery as post certified nursing; 3 ) direct-entry certified midwifery. A Certified Nurse-Midwife (CNM) is an advanced practice nurse that has specialized education and training in both nursing and midwifery. CNM's function is to provide primary health care for women and, most often, for relatively healthy women, whose birth is considered as uncomplicated and not "high risk," as well as their neonate.

In Indonesia, there are several differences compared with global standards. Maternity services or obstetric gynecological care in the hospitals are offered by medical doctors, obgyn consultants, and midwives. Based on Undang Undang Nomor 38 tahun 2014 pasal 4 ayat 2 , nurse profession involved nurse and specialist (maternity, pediatric, psychiatric, community, medical surgical nurse).

According to gold standard, nursing profession is guided by code of ethics that regulates relationships between professional and patient, indicates common culture, norms and values between members, clear standard of educational preparation for entry into practice. Standards of clinical practice guide the practice of nursing regardless of the area of specialization including maternity care services. In regards to this matter, Indonesian nursing has been working to improve the curriculum and health services by providing licensing, certification, accreditation for profession.

In addition, there is a gap between the curriculum level and practical level for maternity nurses. Nursing students learn all the knowledge and practical procedures related to antenatal, intranatal and post natal care of women. However, their knowledge has not been applied in the practical level either inside or outside hospital settings. One of the dilemma of applying their competence is due to the absence of nursing regulation and professional nursing license to practice maternity care services.

The other issues are whether the existing theory is held to be relevant or irrelevant to practice. A lot of literatures on the relation of theory and practice assume that there is a body of relevant intellectual knowledge which should inform nursing practices. The "gap" arises when this body of knowledge is not used as it should be. Moreover, the still-existing debates about overlapping knowledge and practice among some health professionals (MDs, nurses and Midwives) remain as "gray areas" related to maternity health services.

Furthermore, there is a serious shortfall (by international standards) of qualified nurses in Indonesia, with the estimation of 50 nurses per 100,000 populations. Majority of nurses $(60 \%)$ are high school level graduates only; $39 \%$ are diploma holders; and 1\% are graduate degree holders. The latter two groups typically proceed into education soon after completing their training. This means, not only do nursing educators have little clinical experience in the field, which could compromise their teaching competence, but also majority of direct clinical care is delivered by least qualified nurses. Thus, it appears that there is little differentiation between clinical roles of different education levels. Moreover, there is no central registration of nurses; which means it is impossible to regulate the nursing profession, to enforce standard of quality and to ensure accord between levels of training and clinical activities undertaken. Like all government employees, nurses are required to have IPA (individual performance assessment) as a mechanism by which quality standards can be monitored and maintained through CPD. The structure and framework of these IPAs vary greatly, and they affect nurses' understanding of their skill levels and development needs.

In relation to effectiveness and efficiency at the operational level, health care professionals have significant responsibility to manage health care delivery within a framework of limited provision and great environmental diversity. The health care system, widely accepted to be underfunded with the national health budget allocation of just $2 \%$ of GNP, also suffers from the shortage of health equipments, supplies and personnel, aside from lack of professional education and training.

Given that much of Indonesia's health care is delivered through an extensive primary care system which relies heavily on midwives and nurses for its efficiency and success, it seems self-evident to note that the preparation of health personnel is crucial to improve the 
Laili Rahayuwati : Standard, Effectiveness, Efficiency and Sustainability of Maternity Nursing Care

effective functioning and delivery of clinical services. In addition, due to the pressure of public health service needs and the wide variations in population's degree of health, continuous updating or ongoing training of health care professionals is required if they are to meet specific local needs adequately. Consequently, nurses must not only develop clinical skills to manage serious diseases, but also to be culturally competent in order to be sensitive to the cultural needs of patients and families, while simultaneously be able to operate in adverse environmental conditions with limited equipment and resources.

The challenge to both government and individual nurse is very considerable; it means, not only is it essential to attend to basic training of nurses in order to produce essential skills and competence required, but that continuing professional development (CPD) is also required to let them be informed and updated on their knowledge, skills and competence.

Based on current health delivery model, it can be recommended that the obstetrical care can be assumed by all health providers (physicians, specialists and registered $\mathrm{OG}$ Midwives, registered nurse) through a collaborative care model or teamwork, as demonstrated by figure 1 .

Inter-professional collaboration is a partnership between a team of health providers and patient in a participatory, collaborative and coordinated approach to shared decision-making on health and maternity services. Regarding professional role, the professionals understand their own roles and the role of other professions, and then utilize their knowledge and expertise appropriately to establish and meet patient/family's needs and goals. Inter-professional teamwork refers to professional's active engagement with self and others, including the patient/client/family, in dealing effectively with inter-professional goal. Team functioning refers to the understanding of principles of team dynamics and group processes to enable effective interprofessional team collaboration. Finally,

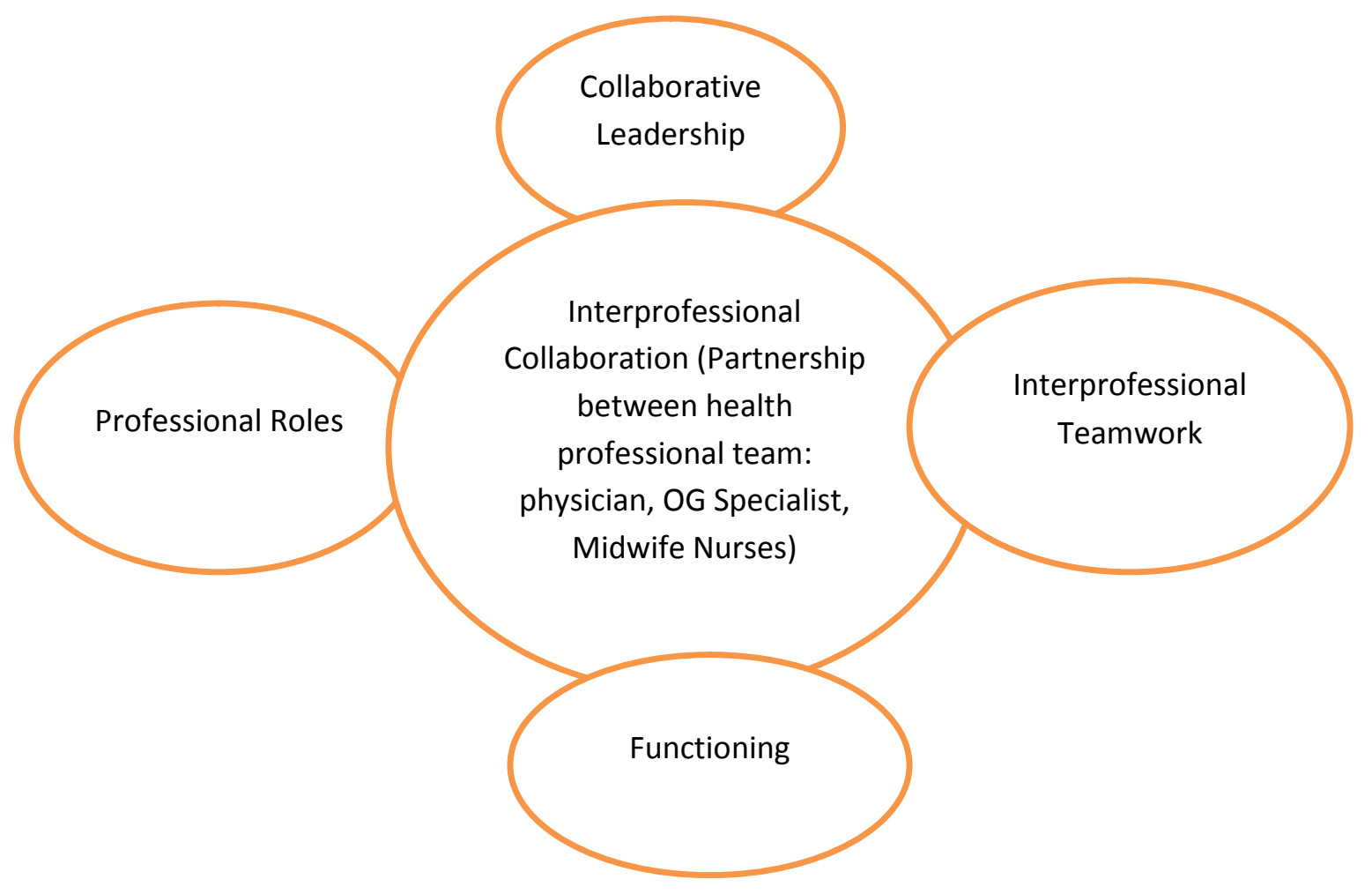

Figure 1 The Collaboration Model in Maternity Services 
Laili Rahayuwati : Standard, Effectiveness, Efficiency and Sustainability of Maternity Nursing Care

collaborative leadership means that every professional works together with other professionals, including patients/clients/ families, to formulate, implement and evaluate the care/services in order to enhance the quality of health services and patient's degree of health.

\section{Conclusion}

The challenge of nursing is trying to discover what knowledge is specifically appropriate to maternity nursing profession; as there is an increasing recognition that knowledge both from the humanities and other sciences should be part of maternity nursing training and formation and that there should not be a hierarchy of knowledge; rather all kinds of knowledge should be valued equally and combined for the best interest of patients. Because maternity nursing science is multifaceted, maternity nurses need to take an eclectic approach, i.e. to choose the best from different sources of knowledge.

Policies must consider local health needs, current state of health services, mixed providers, available resources, health production and training capacity. They must focus on the regulation of health practitioners, standardization of educational programs, adequate support for nursing and midwifery, and the promotion of research within and outside the health sector to address significant gaps in policy development. Furthermore, the action plan includes the mobilization of resources to strengthen nursing and midwifery services comprehensively at every level of health sector: PHC renewalbased strategies to improve access to nursing and midwifery services; policies for interprofessional collaboration in education and practice; nursing midwifery related items to be included in the agenda of national, regional and global meetings and conferences.

The sustainable utilization of nurses and midwives, including within service networks (either within or outside of hospitals) and inter-professional teams models, are identified, adapted and disseminated for regulating, monitoring and evaluating nursing and midwifery services. Nursing and midwifery standards of practice for person- centered care are incorporated. Further evaluation related to nursing curriculum and the implementation of competence in other delivery systems might offer potential factors to improve maternity nursing care at all levels of the health care system in this country.

\section{References}

Badan Litbangkes Depkes RI. (2014). Survei Kesehatan Rumah Tangga. Jakarta.

Badan Pusat Statistik/BPS. (2015). Statistical Year Book of Indonesia.

Charmin,B.(2015). RadioRepublikIndonesia: AKI jadi Tanggung Jawab Pemerintah dan Seluruh Lapisan Masyarakat. Diperoleh dari http://rri.co.id/post/berita/221846/nasional/ aki_jadi_tanggungjawab_pemerintah_dan semua_lapisan_masyarakat. Html pada $\overline{8}$ Februari 2016.

Goverment in South of Australia. (2010). Guide for Maternal and Neonatal Services.

Green, L.W; Kreuter, M.W. (2000). Health Promotion Planning: An Educational and Environmental Approach, Mountain-London: Mayfield Publishing Company.

Hasan Sadikin Hospital. (2002). Medical Record, Bandung, West Java. Unpublished.

Ministry of Health and Population (MOH). Cost Analysis and Efficiency of Health Care. Data for Decision-making, Harvard School of Public Health, University of California, Berkeley, School of Public Health.

Nissa, A.A., Suryani, \& Mardiyaningsih, E. (2013). Gambaran kepuasan pasien terhadap pelayanan antenatal care. Jurnal Keperawatan Maternitas. ISSN 2338-2066 PPNI.

Round, R, Marshall, B \& Horton, K (2005), Planning for effective health promotion evaluation, Victorian Government Department of Human Services, Melbourne.

Stanhope, Marcia; Lancaster, Jeannete. 
Laili Rahayuwati : Standard, Effectiveness, Efficiency and Sustainability of Maternity Nursing Care

(1998). Community Health Nursing. Process and Practice for Promoting Health. Mosby Year Book, St. Louis-Toronto.

Sujudi. (1998). Health Promotion Towards the 21 st Century Indonesian Policy for he Future. Minister of Health, Republic of Indonesia. presented at the 4th International Conference on Health Promotion, New Players for a New Era Leading Health Promotion into the 21st Century, Jakarta, 21-25 July.

Untoro, R., Sri Hermiyanti, Chazali Husni Situmorang., Abas Basuni. (2009). Healthy Next Generation: Strengthening Joint Collaboration Between Health and Social Welfare. Indonesia Country Report. 8-11 September 2009 Tokyo, Japan The 6th ASEAN \& Japan High Level Officials on Caring Societies.

WHO. (2008). Indonesia Mortality Country Fact Sheet.
WHO. (2009). Global Standards for the Initial Education of Professional Nurses and Midwives, Geneva.

WHO. (2010). Nursing Midwefery Strategies Direction 2011-2015, Geneva Switchzerland.

The Future of Nursing: Leading Change, Advancing Health http://www.nap.edu/catalog/12956.html.

ICN. (2006). The Global Nursing Shortage: Priority Areas for Intervention: Geneva, Switzerland. 2006.

ICN. (2006). An Aging Nursing Workforce http://www.icn.ch/matters ageing Workforce.htm (accessed January 15, 2009).

ICN. (2009). The Role and Identity of the Regulator: An International Comparative Study: Geneva, Switzerland. 